\title{
Ability to Write Anecdote Text by Using Caricature Media on 10th Grade Students of SMA Swasta Swakarya Binjai
}

\begin{tabular}{|c|c|}
\hline Muhammad Natsir ${ }^{1, *}$ & 3ahagia Saragih² | Rafika Dewi ${ }^{3}$ | \\
\hline $\begin{array}{l}1,2,3 \text { English and Literature } \\
\text { Department, Faculty of } \\
\text { Languages and Arts, } \\
\text { Universitas Negeri Medan, } \\
\text { Indonesia } \\
{ }^{1} \text { Natsirfbs@unimed.ac.id } \\
{ }^{2} \text { gyabucks123@gmail.com } \\
{ }^{3} \text { fildzafayyadh@gmail.com }\end{array}$ & $\begin{array}{l}\text { ABSTRACT } \\
\text { This study aims to determine the effect of caricature media on the } \\
\text { ability to write anecdote text on 10th Grade Students of SMA } \\
\text { Swasta Swakarya Binjai School Year } 2018 / 2019 \text {. The population of } \\
\text { this research is } 125 \text { students. Of the } 125 \text { students, a sample of } 35 \\
\text { students are selected who were taken using a random sample. The } \\
\text { method used in this study is a quasih experimental two group post- } \\
\text { test design. The instrument used to collect data is the description } \\
\text { test. Hypothesis testing is done using the " } t \text { " test. The data } \\
\text { obtained show that the students 'ability to write anecdote text } \\
\text { without using caricature media is in the sufficient category with } \\
\text { the mean value obtained by the students is } 66.04 \text {, while the } \\
\text { students' ability to write anecdote texts using caricature media is } \\
\text { classified as good with average. (mean) obtained by students } 76.6 \text {. } \\
\text { Furthermore, the hypothesis test shows } t \text { - o> } t \text { (table) and } 7.23> \\
2.03 \text { at the significant level } \alpha=0.05 \text {. Thus, it means that HO is } \\
\text { rejected and Ha is accepted, which means that there is an influence } \\
\text { of caricature media on the ability to write anecdote text on } 10 \text { th } \\
\text { Grade Students of SMA Swasta Swakarya Binjai School Year } \\
2018 / 2019 \text {. Based on the data analysis above, it can be concluded } \\
\text { that the results of learning to write anecdote text using caricature } \\
\text { media have a positive effect on students' ability to write anecdote } \\
\text { text. } \\
\text { KEYWORDS } \\
\text { caricature media; anecdote text; writing }\end{array}$ \\
\hline
\end{tabular}

\section{INTRODUCTION}

The 2013 curriculum on Indonesian language learning is directed at improving students' ability to think critically. This curriculum demands that learning Indonesian is not just using Indonesian to convey learning material but must learn the meaning and choice of the right words. The competency standard of Indonesian language learning is used as a measure of the student's ability to describe the mastery of language knowledge and skills. In this curriculum, Indonesian language learning is text-based. Text is interpreted as a language unit that expresses meaning contextually. Text can be in the form of written text or oral text which is an expression of the human mind. Language has a very important function in the process of communication (Purba, 2018). The language used in the text reflects the ideas, attitudes and values of its users because language is a means of forming human thinking abilities.

Learning Indonesian language itself has four skills that must be mastered, namely, listening, speaking, reading and writing. In general, listening and speaking skills are skills 
that prioritize spoken language, while reading and writing skills are skills that use good written language.

One of the abilities that must be possessed by students is the ability to write. The ability to write is an important life skill, both in education and society. This is because each student's writing skills cannot be acquired naturally but must be trained and honed. Through writing activities, we can express what is in our thoughts and feelings.

Learning Indonesian at the high school / vocational / MA level is learning about text. One form of learning activity in the 2013 Curriculum is producing/writing anecdote text. This is by Basic Competence 4.2 Producing / writing anecdotes by the characteristics of the text to be made both orally and in writing. The ability to think creatively and student activities must be a factor highly considered in the teaching-learning process (Pratiwi, 2019).

Anecdotes are short stories that are interesting because they are funny and memorable, usually about important people or based on actual events (Danandjaja in Fatimah, 2013). Anecdote texts are useful not only to entertain or excite laughter but to reveal a truth more general than the short story itself. In this competency, students are required to be able to write anecdote texts that are by the structure, characteristics, and language. Learning to write anecdote texts is expected to be able to guide students to further develop skills in writing anecdote texts critically and creatively. Writing anecdotes is one of the basic competencies to write skills contained in the high school curriculum (Permadi et al, 2018).

The fact is that the learning results in writing anecdote texts are still far from being "satisfying". This is due to the minimal implementation of the 2013 Curriculum at the high school level (SMA) in the 2018/2019 academic year because in 2013/2014 the government still selected and designated certain schools to be used as trials for implementing the 2013 curriculum. So that in this academic year Many schools are still blind to the 2013 curriculum. As a result, many things are constrained, one of which is the application of learning models or the use of media to subject matter so that students do not understand what the teacher says and are less motivated.

This is in line with the results of observations and interviews conducted pre-research, the competence regarding anecdote texts has not been fully mastered by students. The results of interviews conducted with class X Indonesian language subject teachers at Binjai Private High School showed that writing anecdote texts was still below the minimum completeness criteria value of 71 . This was due to several obstacles, such as most students were lazy in writing anecdote texts, were bored with lessons. Also, the learning model used is less precise and does not vary, and only assigns students to write anecdote texts by fulfilling the text structure without showing how the anecdote text is good and correct.

Nowadays many teachers in schools only use student handbooks in teaching and learning activities. So that learning activities take place less effectively and end up feeling bored from within the student.

One way to improve students 'writing skills is to use appropriate media and be able to stimulate students' writing skills. By using the right media, information or teaching materials can be accepted and absorbed by students well. This is one of the functions of the instructional media, namely to improve properly, so that the results of teaching and learning will increase.

The role of the teacher is very important, considering that the teacher is a central agent in curriculum development and as an architect in classroom learning. In connection with this fact, it is necessary to develop more basic improvement efforts. One of the right solutions to deal with this problem is to use learning media that is suitable and by the text that will be produced later, such as caricature media. 
Through unique and funny caricature media, students will be interested in learning. This media will affect the concentration of students to absorb information maximally. Research efforts on writing anecdote texts with caricature media, as long as the information that the author can reach has never been done by others. On this basis, the authors feel the need to research anecdote text writing skills to do, it is feared that the teaching and learning methods carried out by teachers today will continue to be static and monotonous from time to time. The result is that student achievement over time will be at the same level as well.

Rini Ariska (2014) in her research journal states that the use of caricature media can improve the quality of the learning process to write poetry for $7^{\text {th }}$ grade students of SMP Negeri 1 Bintan in 2013/2014 academic year. The ability to write poetry using caricature media belongs to the good category with an average score of 81 , namely 18 students who get a score of 85-100, 11 students who get a score of 76-84, and 11 students who get a score of 56-67.

Based on the description and facts above, this paper tries to discuss The Increased Ability to Write an Anecdote Text by Using Caricature Media on $10^{\text {th }}$ Grade Students of SMA Swasta Swakarya Binjai School Year 2018/2019.

\section{LITERATURE REVIEW}

\section{The Technique of Selecting Caricature}

Of the number of caricatures that exist, not all of them have the criteria as a weighty caricature. Therefore, knowledge of the quality of these caricatures is very helpful in choosing caricatures for learning purposes. The caricature is derived from the word of caricare (Italian) which means giving extra change or additional (Syamsuri and Mushin, 2016). B.A.I. (2011) states that a caricature is a form of an image that is cliche, satire, criticism and funny.

Rivai (1991) determines several techniques for selecting caricatures for learning, namely:

1. Its use is by student experience,

2. Simplicity,

3. A clear symbol. The first consideration implies that the caricature can be understood by students when the caricature is used.

Schaffer's research (via Rivai, 1991:59) reveals that a good caricature only contains important things. Simplicity in the caricature refers to the simplicity of the physical depiction of the character or atmosphere that is displayed and the brief description that is included in the caricature. Some caricatures do not require any explanation because the physical image itself is sufficient to represent the idea the caricature is trying to convey. As a form of art, caricature is a firm and effective means of communicating with simplicity.

More detailed caricature selection techniques for learning media are as follows:

1. A humorous caricature depiction.

2. The existence of certain parts to show the characteristics of a character or the special meaning of a warm important event.

3. The use of scratches is effective, simple and not much adornment.

4. Supportive caricature appearance.

5. By student experience.

6. Caricatures contain messages or ideas based on facts (events that actually happened) and not caricature imaginations.

7. Caricatures contain criticism of events that are still hot. 


\section{The Advantages of Caricature as a Learning Media}

As a learning medium that serves to attract students' interest in learning. The caricature has the following advantages.

1. Use of symbolism that is brief and to the point.

2. Suggest an idea or message, the event is aesthetically pleasing, funny, satirical and ridiculous.

3. Convey ideas or messages, events in a stereotypical manner, easily recognized by the public.

4. Does not require a lot of descriptions or words.

\section{RESEARCH METHODS}

The research method is a way to find the truth by collecting and analyzing the data needed to achieve the research objectives. With a research method that can be expected to answer the challenges and problems that exist.

The use of appropriate methods is based on problems and research data acquisition. The method used in this study is the experimental method. Sugiyono (2010:107) says "experimental research methods are methods used to seek the effect of certain treatments on others under controlled conditions. " Furthermore, this experimental research uses the Two Group Post-Test Design model.

In this study, the subjects are divided into two groups, namely, the first group as the experimental group and the second group as the control group. The experimental group is a class that is given learning using caricature media in writing anecdote texts. While the control class is a class without using caricature media to write anecdote text. Both groups are given the same material according to the stages of their activities.

The data obtained are then analyzed statistically with analysis steps, namely the test result data arranged in a table form, determining the average value and standard deviation of the two sample data, calculating the normality test, homogeneity test, and hypothesis testing. After $t$ is known, the value will be consulted with the table at the 5\% significant level with degrees of freedom $(\mathrm{dk})=\mathrm{n}-1$ at the real level $\alpha=0.05$. Thus, if to $>t_{t}$ at the real level $\alpha=$ 0.05 , then $\mathrm{H}_{\mathrm{a}}$ is accepted.

\section{RESULTS AND DISCUSSION}

\section{Findings}

The Ability to Write Anecdote Text without Using Caricature Media on 10th Grade Students of SMA Swasta Swakarya Binjai School Year 2018/2019

From the data, it can be seen that the students' ability to write anecdote texts is in the Excellent category with a total value of 85 as many as 1 student. Good category with a total value of 80 as many as 1 student, a total value of 75 as many as 6 students, and a total value of 70 as many as 5 students. Enough category with a total value of 65 as many as 12 students, a total value of 60 as many as 6 students, and a total value of 55 as many as 2 students. Less category with a total value of 50 as many as 2 students. The average ability of students in writing anecdote texts without using caricature media with an average score of 66.14 was in the Enough category.

\section{The Ability to Write Anecdote Text by Using Caricature Media on $10^{\text {th }}$ Grade Students of SMA Swasta Swakarya Binjai School Year 2018/2019}

The ability to write anecdote text of students was included in the Excellent category with a total value of 95 as many as 1 student, a total value of 90 as many as 1 student, and a total 
value of 85 as many as 7 students. In the Good category with a total value of 80 as many as 8 students, a total value of 75 as many as 8 students, and a total value of 70 as many as 6 students. In the Enough category, the total value of 65 is 1 student, the total value of 60 is 0 students, and the total value of 55 is 2 students. The average ability of students in writing anecdote texts using caricature media with an average score of 76.71 was in a Good category.

\section{The Increased Ability to Write Anecdote Text by Using Caricature Media on $10^{\text {th }}$ Grade Students of SMA Swasta Swakarya Binjai School Year 2018/2019}

The students' ability to write anecdote texts without using caricature media was classified as sufficient with an average score of 66.14 , while the ability to write anecdote texts using caricature media was classified as good with an average score of 76.71 .

The test to be tested in this study is $\mathrm{H}_{\mathrm{a}}=$ there is a significant effect between caricature media on the ability to write anecdote text on $10^{\text {th }}$ Grade Students of SMA Swasta Swakarya Binjai School Year 2018/2019. Before being tested based on the data requirements test, the hypothesis was changed to a null hypothesis $\mathrm{H}_{0}=$ there was no significant effect between caricature media on the ability to write anecdote text on $10^{\text {th }}$ Grade Students of SMA Swasta Swakarya Binjai School Year 2018/2019. Before testing the hypothesis, first, the data analysis requirements are tested, namely: normality test, homogeneity test and hypothesis testing.

\section{Discussion}

This research was an experimental study using a two-group post-test design model. The data obtained from this study were data on writing anecdote texts on $10^{\text {th }}$ Grade Students of SMA Swasta Swakarya Binjai School Year 2018/2019. Sample part of the population taken at random. One of them is random sampling, which is a technique of taking samples from the population using simple random or random.

Learning to write anecdote texts that had been discussed previously, the average value of the students' ability to write anecdote texts without using caricature media, is 66.14 with sufficient categories, besides that when viewed from the Minimum Completeness Criteria, then the average value to write text The student anecdote was in the incomplete category because it is below the value of 75. Then the average value of the students' anecdote text writing ability using caricature media is 76.71 with a good category, besides that when viewed from Minimum Completeness Criteria, then the value The average student writing news text was in a complete category because it was above 75 .

Caricature media was effectively used in improving students' anecdote text writing skills, this could be seen in the differences in the scores of students writing anecdote texts without and using caricature media. Thus, it could be concluded that learning using caricature media affects improving students' anecdote text writing skills.

\section{The Ability to Write Anecdote Text without Using Caricature Media on $10^{\text {th }}$ Grade Students of SMA Swasta Swakarya Binjai School Year 2018/2019}

Based on the aspects of the assessment to write skills in writing anecdote texts that had been discussed previously, the learning outcomes of students in writing anecdote texts were in the moderate category because they were at an average of 66.14. Based on the Minimum Completion Criteria, the average score of students was in the incomplete category because it is below the value of 75 . This could be seen from the frequency of assessments where the number of students fell into the sufficient category of $57.14 \%$. From these data also obtained a standard deviation of 8.6 and a standard error of 1.48 . While the data was normally distributed with $\mathrm{L}_{\text {_count }}<\mathrm{L}_{\text {table }}$ which is $0.14<0.15$. The ability to write anecdote texts without 
using caricature media is in the sufficient or incomplete category and is not yet included in the very good category.

As presented in the results of the study, that the validity of this is by the research conducted by Maya Agustahnia (2015) in a journal entitled "The ability to write anecdote text on $10^{\text {th }}$ grade students of Madrasah Aliyah Negeri Bintan in the 2014/2015 academic year" states, "Writing skills Anecdote texts on $10^{\text {th }}$ grade students at Madrasah Aliyah Negeri Bintan are still low. This is obtained from the research data from the subject of Indonesian language on $10^{\text {th }}$ grade students of Madrasah Aliyah Negeri Bintan. The data revealed that the average score obtained by students in writing anecdote texts was only 58.47 , only 1 student $(3.125 \%)$ was able to meet the Minimum Completion Criteria score with a value of $\geq 70$. Thus, $10^{\text {th }}$ grade students of SMP Madrasah Aliyah Negeri Bintan have not yet reached the specified minimum. This is due to internal factors that consider learning to write anecdote texts difficult, especially bringing up anecdote ideas and forming sentence structures."

So based on the Minimum Completion Criteria, the average score of students is in the incomplete category because it is below the value of 75 . This is because without using caricature media, students still have difficulty expressing their ideas in writing anecdotes, students still have difficulty developing and connecting words. into a sentence, from the sentence will form a unified paragraph. Judging from the results of student work without using caricature media, students are still lacking in determining the structure of the text, namely abstraction $\wedge^{\wedge}$ orientation $\wedge^{\wedge} \operatorname{crisis}^{\wedge}$ reaction ${ }^{\wedge} \operatorname{coda}($ text structure must be sequential); linguistic characteristics, namely using conjunctions, using figures of speech, using command sentences which are marked with an interjection word, contains syntax and has a rhetorical question; as well as text content, namely content according to the theme and content not according to the theme. Students also have not found the right way to write anecdote texts, so that students are less able to write good and correct anecdote texts. At this stage without using caricature media, students practice improving their ability to write anecdote texts only by writing what they know, without being given interesting directions to write anecdote texts logically and systematically.

\section{The Ability to Write Anecdote Text by Using Caricature Media on $10^{\text {th }}$ Grade Students of SMA Swasta Swakarya Binjai School Year 2018/2019}

The ability to write anecdote texts at this stage is divided into three categories, namely the excellent category of 9 students or $26 \%$, the good category of 23 students or $66 \%$ and the moderate category of 3 students or $8 \%$. Based on the assessment aspects in writing anecdote texts that have been discussed previously, the results of the ability to write anecdote texts at the post-test stage were included in the good category, namely 23 students or $66 \%$ with an average value of 76.71 and a standard deviation of 8.4. The data is normally distributed with $\mathrm{L}_{\text {count }}<\mathrm{L}_{\text {table }}$ that is $0.08<0.15$.

In line with that, Rini Ariska (2014) in her journal entitled "The Ability to write Poetry Using Caricature Image Media on $8^{\text {th }}$ Grade Students of Junior High School 1 Bintan Tahnun Pelajaran 2013/2014" states, the ability to write poetry on $8^{\text {th }}$ Grade Students is quite satisfying. The use of caricature image media in learning poetry in class VIII students of SMP Negeri 1 Bintan in the academic year 2013/2014 was able to improve the learning process to write poetry to reach an average score of 81 in the good category.

Thus, it is clear that caricature media is a very effective learning medium that teachers can use in delivering teaching materials to students. Caricature media is a learning media that understands the meaning and can teach critical thinking in studying material and understanding its contents. With this technique, students are left to discover on their own or experience mental processes on their own while the teacher only guides and provides 
instructions. The material or lesson material to be delivered is not delivered in a final form, but students are encouraged to identify what they want to know, then continue by looking for information themselves, then organize or shape what they know and understand in a final form. So that with the application of this media students become more aware and enthusiastic in pouring all the ideas they have into writing and arranging sentence by sentence into a complete text. With the application of this media in learning, teachers can improve student learning outcomes, this is evident from the results of research and data obtained.

\section{The Increased Ability to Write Anecdote Text by Using Caricature Media on $10^{\text {th }}$ Grade Students of SMA Swasta Swakarya Binjai School Year 2018/2019}

As presented in the results of the study, which shows the average score for students' writing ability at the stage without using caricature media is in enough category with an average value of 66.14 compared to the stage using caricature media which is categorized as good with an average value of 76,71 with a percentage increase of 10.57 or $30.2 \%$. So from these data it can be found that caricature media affects improving the ability to write anecdote texts.

Based on the research results, the data without and using caricature media were normally distributed. This can be seen from the data normality test without and by using caricature media. From the homogeneity data it is also evident that the sample of this study comes from a homogeneous population. And hypothesis testing has proven that the alternative hypothesis $\left(\mathrm{H}_{\mathrm{a}}\right)$ is accepted. Thus, this caricature media has a significant effect on the ability to write anecdote text on $10^{\text {th }}$ Grade Students of SMA Swasta Swakarya Binjai in the 2018/2019 academic year.

\section{CONCLUSION}

Based on the research results that have been described in the discussion, it can be concluded that the ability to write anecdote text on $10^{\text {th }}$ Grade Students of SMA Swasta Swakarya Binjai in the 2018/2019 academic year without using caricature media is in the sufficient category with an average score of 66.14 with the highest score of 85 and as low as 50 and a standard deviation of 8.6. If you look at Minimum Completion Criteria 75, the students' ability to write anecdote texts has not been achieved.

The ability to write anecdote text on $10^{\text {th }}$ Grade Students of SMA Swasta Swakarya Binjai in the 2018/2019 academic year using caricature media is in the good category with an average score of 76.71 with the highest score of 95 and the lowest of 65 and a standard deviation of 8.4. If you look at Minimum Completion Criteria 75, the students' ability to write anecdote texts has been achieved.

Learning with caricature media has a significant effect on the ability to write anecdote text on $10^{\text {th }}$ Grade Students of SMA Swasta Swakarya Binjai in the 2018/2019 academic year with the results of the hypothesis, namely t_o> $t_{-}$(table) and 7.23>2.03 which means that $\mathrm{H}_{\mathrm{a}}$ is accepted. Because this media can provide suggestions in increasing children's attention in participating in the teaching and learning process.

\section{REFERENCES}

Agustahnia, Maya. (2015). Kemampuan Menulis Teks Anekdot Siswa Kelas X.1 Madrasah Aliyah Negeri Bintan. Tanjung Pinang: Jurnal Universitas Maritim Raja Ali Haji

Ariska, Rini. (2015). Kemampuan Menulis Puisi Dengan Media Gambar Karikatur Siswa Kelas Viii Sekolah Menengah Pertama Negeri 1 Bintan. Tanjung Pinang: Jurnal Universitas Maritim Raja Ali Haji. 
B. A. I, Ju. (2011). Yi Chun Cartoon and Caricature Development of Cultural Industry Pattern Studies. Journal of Yichum College.

Fatimah, Nuraini. (2013). Teks Anekdot Sebagai Sarana Pengembangan Kompetensi Bahasa dan Karakter Siswa. Skripsi FBS Universitas Muhammadiyah Surakarta

Permadi, Dody Satria., Saragih, Amrin., and Saragi, Daulat. (2018). Development of Anecdote Text Writing Teaching Materials Based on Process Approach for Students Class X SMA Negeri 1 Stabat. International Journal of Education Learning and Development, 6(8), 71-78.

Purba, Rodearta. (2018). Improving the Achievement on Writing Narrative Text through Discussion Starter Story Technique. Advances in Language and Literary Studies. 9(1), 28-30.

Pratiwi, Veronika Unun. (2019). Implementing Think Talk Write Strategy to Enhance Students of High School's Writing Skill in Narrative Text. European Journal of Social Sciences, 57(4), 408-418.

Rivai, Ahmad. (1991). Media Pengajaran. Bandung : Bina Baru.

Sugiyono. (2009). Metode Penelitian Pendidikan. Jakarta: Alfabeta

Syamsuri, Andi \& Muhsin, Muh Arief \& Nurmayani, Nurmayani. (2016). The Effectiveness of Caricature Media in Learning Writing of Argumentation Paragraph. Theory and Practice in Language Studies, 6(11), 2079-2084. 